\title{
The Impact of the Announcement of First Covid-19 Case in Indonesia on Property and Real Estate Companies' Stock Returns and Trading Volume
}

\author{
Syane Rachma Dian ${ }^{1, *}$ Astrie Krisnawati ${ }^{2}$
}

${ }^{1}$ Telkom University

${ }^{2}$ Telkom University

*Corresponding author.Email: syanerd@student.telkomuniversity.ac.id

\begin{abstract}
COVID-19 pandemic is a great disaster that affects all aspects of human life. Inevitably, COVID-19 also has impacts on economic activities throughout the world, including investment activities. It also affects the investors' behavior in Indonesia Stock Exchange (IDX). The changes in investors' behavior can lead to abnormal returns and the shifting of the volume of stocks being traded. The COVID-19 pandemics make most property and land businesses in Indonesia experience dejections in their financial performance. Along these lines, this research expects to evaluate whether the COVID-19 pandemic fundamentally impacts the property and real estate sector in IDX in the matter of the stock return and trading volume movement. This reserach utilizes a quantitative method and event study using secondary data of price of stock and stock trading volume. The event of this research is the first COVID-19 case in Indonesia announcement. The window time of this research consists the 10 days prior to the announcement, the D-Day of the announcement, and the 10 days following the announcement (February 17-Walk 16, 2020). The outcomes of this research show that there is no significant difference in average abnormal return and there is a significant difference in average trading volume activity between prior to the first COVID-19 case in Indonesia announcement and following the announcement.
\end{abstract}

Keywords: COVID-19, stock returns, trading volume, property and real estate.

\section{INTRODUCTION}

The first COVID-19 case in Indonesia was reported by the Head of the Republic of Indonesia, Joko Widodo, on March 2, 2020. This is the beginning of an unpredictable stock market in Indonesia, many sectors are affected by this phenomenon, and one of them is the property and real estate sector.

Ellen May of Ellen May Institute stated that subsector property and real estate is greatly impacted because of the COVID-19 pandemic. She took PT Bumi Serpong Damai Tbk as an example. The income that PT Bumi Serpong Damai Tbk got from the stock trading decreased by $57.1 \%$. There was also an IDR1.1 trillion decrease in selling (CNN Indonesia, 2020). The decrease is significantly reflected in apartment sales as the leader of Real Estate Indonesia (REI) Jakarta region stated (Kumparan, 2020).
Since the first COVID-19 case in Indonesia is publicly announced, a lot of business activities need to be halted and/or limited. The limitations of business activities make businesses suffering from losses. This continues to the declining of the economy. This condition is affecting the investors' behavior on IDX. The changes of investors' behavior is reflected on the price of stock and trading volume. 


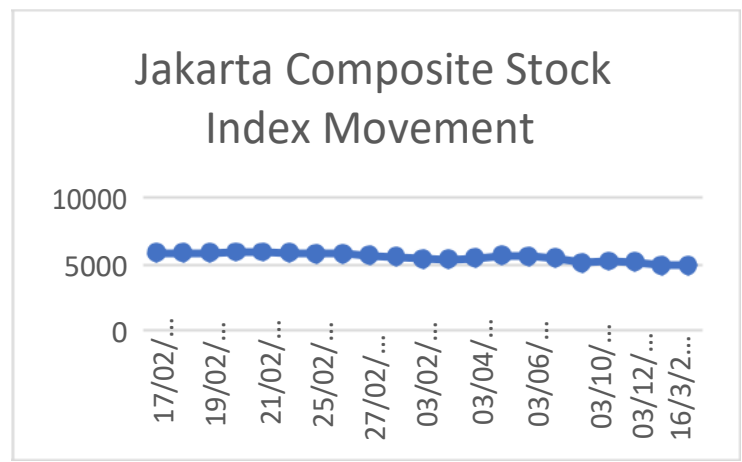

Figure 1 Jakarta Composite Index Stock Movement February 17 - March 16, 2020

Source: www.finance.yahoo.com

Figure 1 shows that prior to the first COVID-19 case in Indonesia is announced, the price of stock was quite stable, although nearing the end of February the price went lower. Following the announcement, the price went up for two days. Then, since March $5^{\text {th }}$ the price was fluctuating, but the trend was going down.

Other than the price of stock, the trading volume activity (TVA) is also affected by the investors' behavior. Figure 2 shows the changes in investors' behavior that are reflected in trading volume activity on IDX.

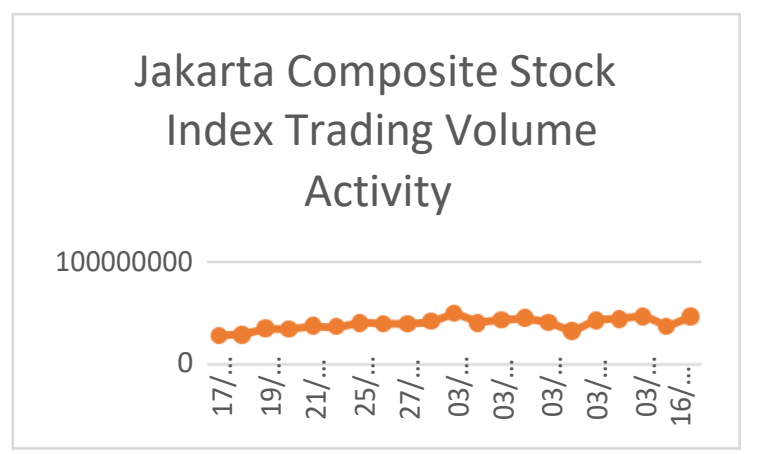

Figure 2 Jakarta Composite Index Trading Volume Movement February 17 - March 16, 2020 Source: www.finance.yahoo.com

As shown by Figure 2, the trading volume kept increasing until the day of the fist COVID-19 case in Indonesia is publicly announced. Since the announcement, the TVA was fluctuating very extremely.

The stock movement was diminishing two days following the first COVID-19 case in Indonesia is publicly announced, and since then it was fluctuating quite extremely. This reflects that the first COVID-19 case in Indonesia announcement affects the investors in making decisions in investing in IDX.

To know how the first COVID-19 case in Indonesia announcement affects the stock market, an event study that estimates average abnormal return (AAR) and TVA will be used. The time window of this event study will be divided into three kinds of group; (1) pre-event range (10 days prior to the announcement), (2) D day (the day of the announcement), and (3) post-event range (10 days following the announcement).

As for the data analysis technique, Shapiro-Wilk will be utilized to test the data normality. If the data is normally distributed paired samples t-test will be applied, and if the data is not normally distributed Wilcoxon test will be applied to test the hypotheses.

The COVID-19 is a factor of today's condition, where fluctuations in stock trading and trading value are presented in the market, including in the property and real estate companies that are registered in IDX. The fluctuation is the factor that affects the price of stock and abnormal return for the investors and the trading volume.

To find out the impact of COVID-19 on the property and real estate companies, the after questions need to be answered through this research.

1. Is there a significant difference in AAR of the property and real estate companies that are registered in IDX, following the first COVID19 case in Indonesia announcement and prior to the announcement?

2. Is there a significant difference in average TVA of the property and real estate companies that are registed in IDX, following first COVID-19 case in Indonesia announcement and prior to the announcement?

Thus, the goal of this study is to answer those three research questions.

\section{LITERATURE REVIEW}

\subsection{Literature Review}

\subsubsection{Investment}

The current commitment of money or other resources with an expectation of reaping future benefitd is called an investment. Investment can be done in two different assets. First, an investment in land, buildings, machines, and knowledge, also known as an investment in real assets. Second, an investment in bonds and stocks, known as an investment in financial assets [15].

\subsubsection{Capital Market}

A capital market is a place where parties who have excess funds meet parties who need funds, and both parties can meet each other's needs by trading their securities. Whereas the place where the transaction of selling and buying of securities is called the stock exchange [4]. 


\subsubsection{Stocks}

[15] states that there are two types of stocks that are issued by companies and published in a stock exchange, which are:

\section{Common Stock}

This type of stock does not give any privilege to its owners. This type of stock is also a way to divide company ownership. It means that one common stock represents one percent of ownership of a company. Each common stock gives a privilege to the owner to have one vote on any matters of corporate governance, which usually being discussed at the annual shareholders' meeting.

\section{Preferred stock}

Preferred stock gives its owners the privilege to get dividends in advance and cumulative dividends. It also gives its owners a fixed amount and specified stream of dividends. In case of bankruptcy, dividends will still be paid. Preferred stock owners also have a right to get their dividends fully paid before the common stock owners.

\subsubsection{Efficient Market Hypothesis}

An efficient market hypothesis is the condition where the price of stock is believed to have reflected all available information [15]. In addition, according to [3], an efficient market is being classified into three forms, which are strong form, semi-strong form, and weak form.

\subsubsection{Market Anomalies}

Market anomalies happen when there are found such findings that are difficult to be reconciled with the efficient market hypothesis. [15] explains that market anomalies can be known through semistrong tests.

\subsubsection{Stock Risk and Return}

1. Risk

[13] explains that risk that is relevant to the investors is measured and expressed in the form of the standard deviation of the portfolio profit rate or can be referred to as cumulative risk.

\section{Return}

[1] states that return is a benefit that is gained from an investment. Return is categorized into two different returns, which are actual and expected returns. Actual return is the actual gain (return) that investors get from an investment and is calculated from the historical data. While the expected return is the gain (return) that an investor expects from an investment.

Actual return is the actual gain or returns that an investor gets from an investment. [10] states that actual return can be calculated by,

Pt: Price of stock on day $t$

Pt-1: Price of stock on day $t-1$
The expected return is the gain or returns that an investor expects to get from an investment. [8] explains that there are three approaches to figure anticipated returns, which are the Mean-Adjusted Model, Market Model, and Market-Adjusted Model.

In this research, the Market-Adjusted Model will be applied to calculate the expected return. The formula of the model is:

$$
\begin{array}{ll}
\mathrm{E}[\mathrm{Ri}, \mathrm{t}] & : \text { expected return stock } \mathrm{i} \text { in } \mathrm{t} \text { period } \\
\mathrm{Rmt} & : \text { market return }
\end{array}
$$

\subsubsection{Abnormal Return (AR) and Average Abnormal Return (ARR)}

[4] explains that AR is the deviation of the actual return and expected return. AR can occur when the information is not published yet, or when the information is lost after it is being published.

[8] states that there are three different ways to calculate the AR, which are the Mean-Adjusted Model, Market Model, and Market-Adjusted Model.

In this research, the Market-Adjusted Model will be applied in order to find the AR. The formula of the model is:
$\mathrm{ARi}, \mathrm{t}=\mathrm{Ri}, \mathrm{t}-\mathrm{Rm}, \mathrm{t}$
ARi,t $\quad$ : Abnormal return for security (i) on (t) period
Ri,t : : Actual return (i) on the (t) period
$\mathrm{Rm}, \mathrm{t} \quad$ : Expected return of market index (m) on $(\mathrm{t})$ period

AAR is calculated from the AR from all types of stocks that are being analyzed daily. [8] states that the AAR can be calculated by the following formula, which is:

$\begin{array}{ll} & \\ \text { AARt } & : \text { Average AR on }(t) \text { period } \\ \text { AR } & : \text { AR firm (i) securities on }(t) \text { period } \\ \mathrm{k} & : \text { The number of securities that are } \\ & \text { affected }\end{array}$

\subsubsection{Trading Volume Activity and Average Trading Volume Activity}

TVA is the total number of shares that are traded at a certain period [12]. A small volume of trades means that there is only a small number of investors who are interested in the stock, or that there is less interest in investing in the secondary market. Whereas a big volume indicates that there is more interest in buying and selling the stock and shows the number of shareholders.

[6] states that TVA can be calculated through this formula, which is:

[5] states that average TVA is calculated from the TVA from all types of stocks that are being analyzed daily. The formula to calculate the average TVA is: 
$\Sigma$

TVA

$\mathrm{n}$

: TVA firm (i)

: The number of securities that are affected

\subsubsection{Event Study}

To measure the effect of an event on price of stock, an event study is usually used. This study is conducted in order to know whether the event might give an effect on price of stock. The effect can be in the forms of AR and the change of TVA.

[15] states that to measure the model of empirical economic studies to analyze the price of stock of a firm regarding how an event is impacting a firm, an AR technique can be used.

In addition, [12] states that TVA measurement can be used in order to know the investors' interest in the market. The changes in trading volume might also be an impact of an event on price of stock.

Therefore, an event study helps in seeing and analyzing the capital market reaction with the changes of price of stock for a particular event. An event study is conducted on a particular event window, in order to compare the differences and see whether such an event is affecting the changes in price of stock.

\subsection{Previous Research}

[2] conducted research. The outcome of the esearch is that during the pre-lockdown there is a notable negative effect on Vietnam's stock returns. However, during the lockdown time span there is a notable beneficial outcome in the whole market's and various business sectors' stock introduction. Similarly, the assessment also communicates that there is an opposing impact between COVID-19 cases and stock returns in Vietnam.

[11] did research. The outcome of the research is that by mid-April the negative impact of COVID-19 has slowly fallen and started to taper off. In addition, COVID-19 influences Asian developing markets the most and European developing markets moderately. Moreover, if the governments take a necessary measure punctually and reported bigger stimulus packages, the effect of the outbreak will be generally more modest.

[7] conducted research. The outcome of the research is that there is a notable gap in the price of stock of PT Ramayana Lestari Sentosa Tbk. The price of stock goes lower following the first COVID-19 case in Indonesia was reported. Moreover. There is likewise a notable gap in the exchanging volume of PT Ramayana Lestari Sentosa Tbk. The TVA goes up after the first COVID19 case in Indonesia was reported.

[9] did research. The outcome of the research is that there is a notable gap in the composite price of stock index at the Indonesia Stock Exchange after the COVID-19 pandemic occurs.

\subsection{Research Framework}

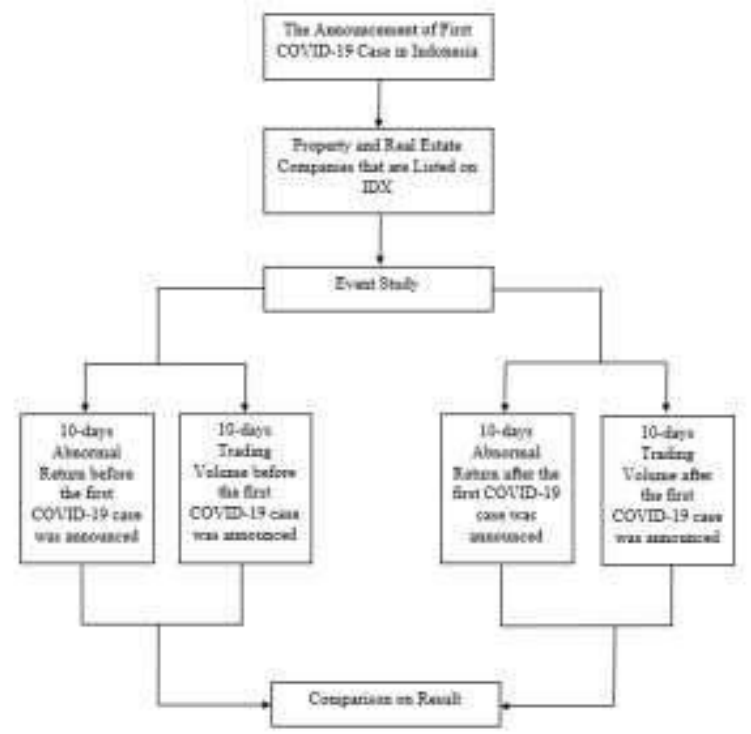

Figure 3 Research Framework

According to the research background, research problem, and research framework, the hypotheses that can be formulated on this study are:

$\mathrm{H}_{1}$ : There is a significant difference in AAR following the first COVID-19 case in Indonesia announcement on property and real estate companies that are registered in IDX.

$\mathrm{H}_{2}$ : There is a significant difference in TVA following the first COVID-19 case in Indonesia announcement on property and real estate companies that are registered in IDX.

\section{RESEARCH METHOD}

The phases of the analysis of the data in this research are as follows:

\section{Define Event Window of Event Study}

On this research, the event window will be 21-days period. It consists of 10-days prior to the event (February 17-February 28, 2020), D-day (March 2, 2020), and 10-days following the event (March 3-March 16, 2020).

2. Calculate Return (Ri,t) using Equation (1).

3. Calculate Expected Return using Equation (2).

4. Calculate AR using Equation (3).

5. Calculate Average AR using Equation (4).

6. Calculate TVA using Equation (5).

7. Calculate Average TVA using Equation (6).

8. Formulate Null-Hypothesis (H0) and Alternative Hypothesis ( $\mathrm{Ha})$

H01 : There is no significant difference in AAR following the first COVID-19 case in Indonesia 
announcement on property and real estate companies that are registered in IDX.

$\mathrm{H}_{\mathrm{a} 1}$ : There is a significant difference in AAR following the first COVID-19 case in Indonesia announcement on property and real estate companies that are registered in IDX.

$\mathrm{H}_{02}$ : There is no significant difference in TVA following the first COVID-19 case in Indonesia announcement on property and real estate companies that are registered in IDX.

$\mathrm{H}_{\mathrm{a} 2}$ : There is a significant difference in TVA following the first COVID-19 case in Indonesia announcement on property and real estate companies that are registered in IDX.

\section{Determine Significance Level}

[14] states that the result that we get still has a probability of error and confidence (the confidence that the result is true), which is called a significance level and is presented in percentage. In this research, the significance level $(\alpha)$ that is used id $5 \%$ of error or 0.05 , and $95 \%$ of confidence or 0.95 .

\section{Normality Distribution Testing}

Normality distribution testing is utilized to test if the data collected is normally distributed or not. In testing the distribution normality, the Shapiro-Wilk test will be utilized. Shapiro-Wilk test has a method of contrasting Asymp. Sig. (2-tailed) with $\alpha=0.05$. If the data is distributed normally, then paired samples t-test will be utilized, and if the data is not normally distributed, then the Wilcoxon test will be applied to test the hypotheses. There are a few standards to characterize the normality of the data, which are:

a. Data is normally distributed if significance $>0.05$.

b. Data is not normally distributed if significance $\leqslant$ 0.05 .

\section{Hypothesis Testing}

To know whether the first COVID-19 case announcement in Indonesia gives a significant impact on AAR and average TVA of property and real estate firms that are registered in IDX or no, a paired samples t-test will be utilized if the data is distributed normally. There are some hypothesis criteria if the data is normally distributed, which are:

a. If the $\mathrm{p}$-value $\leqslant 0.05$, reject $\mathrm{H}_{01}$, and acknowledge $\mathrm{H}_{\mathrm{a}}$. This implies that there is a significant difference in AAR following the first COVID-19 case in Indonesia announcement on property and real estate firms that are registered in IDX.

b. If the p-value >0.05, acknowledge $\mathrm{H}_{01}$, and reject $\mathrm{Ha}_{\mathrm{a}}$. This implies that there is no significant difference in AAR following the first COVID-19 case in Indonesia announcement on property and real estate firms that are registered in IDX.

c. If the p-value $\leqslant 0.05$, reject $\mathrm{H}_{02}$, and acknowledge $\mathrm{H}_{\mathrm{a}}$. This implies that there is a significant difference in TVA following the first COVID-19 case in Indonesia announcement on property and real estate firms that are registered in IDX.

d. If the p-value >0.05, acknowledge $\mathrm{H}_{02}$, and reject $\mathrm{H}_{\mathrm{a}}$. This implies that there is no significant difference in TVA following the first COVID-19 case in Indonesia announcement on property and real estate firms that are registered in IDX.

While if the data is not distributed normally, the Wilcoxon test will be applied. There are some hypothesis criteria under the Wilcoxon test, which are:

a. If sig $>0.05$, acknowledge $\mathrm{H}_{01}$ and reject $\mathrm{H}_{a 1}$. This implies there is no significant difference in AAR following the first COVID-19 case in Indonesia announcement on property and real estate firms that are registered in IDX.

b. If sig $<0.05$, reject $\mathrm{H}_{01}$, and acknowledge $\mathrm{H}_{a 1}$. This implies that there is a significant difference in AAR following the first COVID19 case in Indonesia announcement on property and real estate firms that are registered in IDX.

c. If $\operatorname{sig}>0.05$, acknowledge $\mathrm{H}_{02}$, and reject $\mathrm{H}_{22}$. This implies that there is no significant difference in TVA following the first COVID19 case in Indonesia announcement on property and real estate firms that are registered in IDX.

d. If sig $<0.05$, reject $\mathrm{H}_{02}$, and acknowledge $\mathrm{H}_{\mathrm{a}}$. This implies that there is a significant difference in TVA following the first COVID19 case in Indonesia announcement on property and real estate firms that are registered in IDX. 


\section{DISCUSSION}

\subsection{Average Abnormal Return (AAR)}

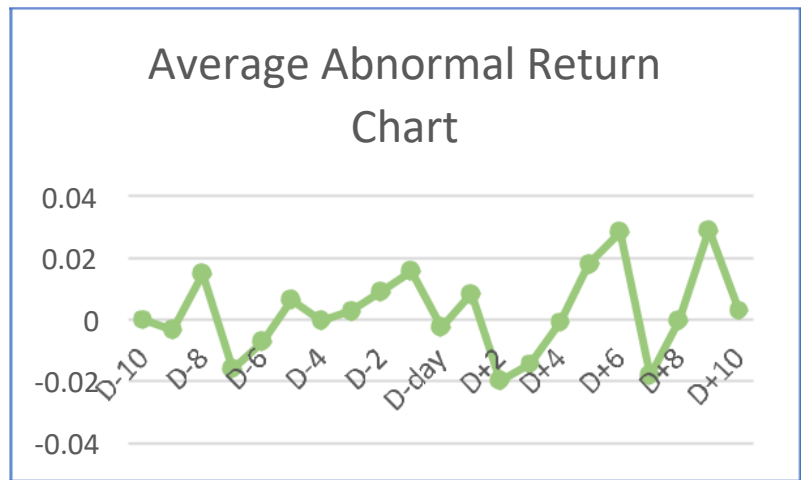

Figure 4 AAR Chart

Source: Processed by author

As seen in Figure 4, 4 days (D-4) prior to the first COVID-19 case announcement in Indonesia, the AAR tends to have a positive trend. However, on the day of the announcement (D-Day), the AAR goes down and it hits the lowest point 2 days following the announcement (D+2) which is -0.0197 or $-1.97 \%$. Since then, the AAR has been fluctuating extremely.

Table 1. AAR Descriptive Statistics

\begin{tabular}{|l|l|l|l|l|l|}
\hline \multicolumn{7}{|c|}{ Descriptive Statistics } \\
\hline & $\mathrm{N}$ & Min. & Max. & Mean & $\begin{array}{l}\text { Std. } \\
\text { Dev }\end{array}$ \\
\hline Before & 10 & -.0158 & .0157 & .0021 & .0099 \\
\hline After & 10 & -.0197 & .0292 & .0055 & .0196 \\
\hline $\begin{array}{l}\text { Valid N } \\
\text { (listwise) }\end{array}$ & 10 & & & & \\
\hline
\end{tabular}

Source: Processed by author

As seen in Table 1, following first COVID-19 case announcement in Indonesia the minimum AAR is lower than prior to the announcement. In addition, in Figure 4 it can also be seen that following the announcement, the AAR fluctuates more extreme than prior to the announcement.
Table 2. AAR Normality Test

\begin{tabular}{|l|l|l|l|l|l|l|}
\hline \multicolumn{7}{|c|}{ Normality Test } \\
\hline \multicolumn{2}{|c|}{$\begin{array}{l}\text { Kolmogorov- } \\
\text { Smirnov }\end{array}$} & \multicolumn{3}{l|}{ Shapiro-Wilk } \\
\cline { 2 - 7 } & $\begin{array}{l}\text { Statis } \\
\text { tic }\end{array}$ & df & Sig. & $\begin{array}{l}\text { Statis } \\
\text { tic }\end{array}$ & df & Sig. \\
\hline $\begin{array}{l}\text { Bef } \\
\text { ore }\end{array}$ & .104 & 10 & $.200^{*}$ & .970 & 10 & .888 \\
\hline $\begin{array}{l}\text { Aft } \\
\text { er }\end{array}$ & .179 & 10 & $.200^{*}$ & .878 & 10 & .125 \\
\hline
\end{tabular}

*: This is a lower bound to the true significance. Source: Processed by author

As stated before, if Asymp. Sig. (2-tailed) > 0.05 data is normally distributed. From Table 2, it is seen that the significances of Shapiro-Wilk are greater than the significance level $(0.888>0.05 ; 0.125>0.05)$. Therefore, the data of AAR is distributed normally. So, to test the hypothesis, the Paired T-Test will be applied.

\subsection{Average Trading Volume Activity (Average $T V A)$}

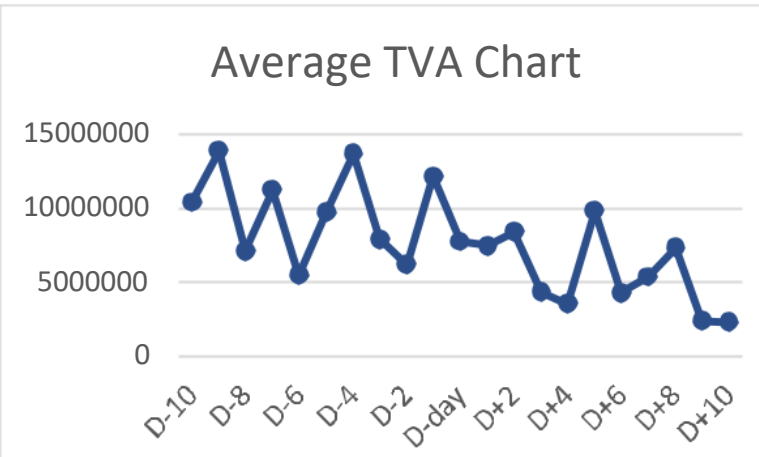

Figure 5 Average TVA Chart

Source: Processed by author

As seen in Figure 5, prior to the first COVID-19 case in Indonesia announcement, the average TVA fluctuates quite extremely. However, the trend of the average TVA prior to the announcement is not necessarily negative. There is a different result once the first COVID-19 case in Indonesia announcement. After the case is announced, although the average TVA is fluctuating, the overall trend is negative with the lowest point 10 days following the announcement (D+10). 
Table 3. Average TVA Descriptive Statistics

\begin{tabular}{|c|c|c|c|c|c|}
\hline \multicolumn{6}{|c|}{ Descriptive Statistics } \\
\hline & $\mathrm{N}$ & Min. & Max. & Mean & $\begin{array}{l}\text { Std. } \\
\text { Dev }\end{array}$ \\
\hline $\begin{array}{l}\text { Bef } \\
\text { ore }\end{array}$ & 10 & $\begin{array}{l}544931 \\
9.512\end{array}$ & $\begin{array}{l}138544 \\
09.76\end{array}$ & $\begin{array}{l}975280 \\
0.976\end{array}$ & $\begin{array}{l}301100 \\
0.532\end{array}$ \\
\hline $\begin{array}{l}\text { Aft } \\
\text { er }\end{array}$ & 10 & $\begin{array}{l}230783 \\
9.024\end{array}$ & $\begin{array}{l}983268 \\
7.805\end{array}$ & $\begin{array}{l}553498 \\
4.634\end{array}$ & $\begin{array}{l}259849 \\
4.038\end{array}$ \\
\hline $\begin{array}{l}\text { Vali } \\
\text { d N } \\
\text { (list } \\
\text { wis } \\
\text { e) }\end{array}$ & 10 & & & & \\
\hline
\end{tabular}

Source: Processed by author

As seen in Table 3, prior to the announcement, the lowest average TVA is 5,449,319.512 and the highest is $13,854,409.76$. While following the announcement the lowest average TVA is 2,307,839.024 and the highest is $9,832,687.805$. So, there is quite a big difference in average TVA after the first COVID-19 case in Indonesia is announced.

Table 4. Average TVA Normality Test

\begin{tabular}{|c|c|c|c|c|c|c|}
\hline \multicolumn{7}{|c|}{ Normality Test } \\
\hline & \multicolumn{3}{|c|}{$\begin{array}{l}\text { Kolmogorov- } \\
\text { Smirnov }\end{array}$} & \multicolumn{3}{|c|}{ Shapiro-Wilk } \\
\hline & $\begin{array}{l}\text { Statis } \\
\text { tic }\end{array}$ & df & Sig. & $\begin{array}{l}\text { Statis } \\
\text { tic }\end{array}$ & df & Sig. \\
\hline $\begin{array}{l}\text { Bef } \\
\text { ore }\end{array}$ & .131 & 10 & $.200 *$ & .970 & 10 & .601 \\
\hline $\begin{array}{l}\text { Aft } \\
\text { er }\end{array}$ & .177 & 10 & $.200 *$ & .878 & 10 & .508 \\
\hline
\end{tabular}

*: This is a lower bound to the true significance.

Source: Processed by author

As stated before, if Asymp. Sig. (2-tailed) > 0.05 data is normally distributed. From Table 4, it is seen that the significances of Shapiro-Wilk Sig. are greater than the significance level $(0.601>0.05 ; 0.508>0.05)$. Therefore, the data of average TVA data is normally distributed. So, to test the hypothesis, the Paired T-Test will be applied.

\subsection{Hypothesis Testing}

As explained before, if the p-value $\leqslant 0.05$, it means that there is a notable impact that the first COVID-19 case in Indonesia announcement gives on the property and real estate firms, which are registered in IDX, AAR and average TVA. In contrast, if the pvalue $\leqslant 0.05$, it means that there is no significant impact that the first COVID-19 case in Indoensia announcement gives on the property and real estate firms, which are registered in IDX, AAR and average TVA.

\subsubsection{Hypothesis Testing of Average Abnormal Return}

Table 5. AAR Paired Samples T-Test

\begin{tabular}{|l|l|l|}
\hline \multicolumn{3}{|c|}{ Paired Samples Test } \\
\hline \multicolumn{3}{|c|}{ Sig. (2-tailed) } \\
\hline Pair 1 & Before .630 After \\
\cline { 2 - 2 } & & \\
\hline
\end{tabular}

Source: Processed by author

As indicated by Table 5, the value of Sig. (2-tailed) of both AAR prior to and following the first COVID-19 case in Indonesia was announced is higher than the significance level $(0.630>0.05)$. Therefore, there is no significant difference in AAR following the first COVID-19 case in Indonesia announcement on property and real estate firms that are registered in IDX.

\subsubsection{Hypothesis Testing of Average TVA}

Table 6. Average TVA Paired Samples T-Test

\begin{tabular}{|l|l|l|}
\hline \multicolumn{3}{|c|}{ Paired Samples Test } \\
\hline \multicolumn{3}{|c|}{ Sig. (2-tailed) } \\
\hline Pair 1 & Before .010 After & \\
\cline { 2 - 2 } & & \\
\hline
\end{tabular}

Source: Processed by author

As per Table 6, the estimation of Sig. (2-followed) of both average TVA prior to and following the first COVID-19 case in Indonesia was announced is lower than the significance level $(0.010<0.05)$. Therefore, there is a significant difference in average TVA following the first COVID-19 case in Indonesia announcement on property and real estate firms that are registered in IDX.

\section{CONCLUSION AND IMPLICATIONS}

\subsection{Conclusion}

As has been explained before, according to the paired samples t-test, there is no significant difference in AAR of property and real estate firms which are registered in IDX between 10 days prior to and 10 days following the first COVID-19 case in Indonesia announcement day. Nevertheless, according to the descriptive test, there is a positive effect that the first COVID-19 case in Indoensia announcement gives to the $\mathrm{AAR}$, as there is an increase in the mean AAR from 0.0021 (10 days prior to the announcement) to 0.0051 (10 days following the announcement). With the fact that there is no significant difference in AAR implies that the investors who are 
investing in property and real estate firms' stocks do not have to worry about their investment.

In contrast, according to the paired samples t-test, there is a significant difference in average TVA of property and real estate firms that are registered in IDX between 10 days prior to and 10 days following the first COVID-19 case in Indonesia announcement. In addition, according to the descriptive test, there is a negative impact that the announcement gives to the average TVA, as there is a critical diminishing in the mean of average TVA from 9,752,800.976 (10 days prior to the announcement) to 5,534,984.634 (10 days following the announcement). The decrease in average TVA of property and real estate firms implies that the number of investors who are keen on purchasing and selling the property and real estate firms' stocks is diminishing. In other words, the property and real estate firms' stocks are not as famous as prior to the announcement.

\subsection{Implications}

The results of this research lead to the after implications:

1. The mean of the AAR of the property and real estate firms that are registered in the IDX prior to the first COVID-19 case in Indonesia announcement (February 17-February 28, 2020) is lower than following the announcement (March 3-March 16, 2020). As such, there is a positive impact that the announcement gives to the AAR of the property and real estate firms that are registered in IDX.

2. The mean of average TVA of the property and property firms that are registered in IDX prior to the first COVID-19 case in Indonesia announcement (February 17-February 28, 2020) is higher than following the announcement (March 3-March 16, 2020). In other words, there is a negative impact that the announcement gives to average TVA of the property and real estate firms that are registered in IDX.

3. According to the paired samples t-test which is utilized to test the hypotheses, there is no significant difference in AAR of the property and real estate firms that are registered in IDX between 10 days prior to (February 17-February 28, 2020) and 10 days following (March 3March 16, 2020) the first COVID-19 case in Indonesia announcement. However, there is a significance difference in averange TVA of the property and real estate firms that are registered in IDX between 10 days prior to (February 17February 28, 2020) and 10 days following (March 3-March 16, 2020) the first COVID-19 case in Indonesia announcement.
4. Investors should not be worried about and recommended to hold their investement in property and real estate firms as there is no significant difference in AAR following the first COVID-19 case in Indonesia is announced. However, the investors are encouraged to sell their stocks as the average TVA is diminishing following the announcement.

5. Firms should not be worried about the AAR that is reflected in the market. However, they should pay attention to the average TVA as it reflects that there is a decrease in interest in their stock.

6. Other researchers are encouraged to do further research with a different type of event that is related to COVID-19 pandemics, such as the announcement of lockdown, the announcement of case increase, and the announcement of the arrival of COVID-19 vaccines.

\section{AUTHORS' CONTRIBUTIONS}

Syane Rachma Dian and Astrie Krisnawati conceived the presented idea. Syane Rachma Dian conducted the literature research, data gathering and data processing, and tests. Astrie Krisnawati supervised the finding of this work. All authors discussed and contributed to the final manuscript.

\section{REFERENCES}

[1] A. Halim, Analisis Investasi: di Aset Keuangan, Mitra Wacana Media, 2015.

[2] D. L. Anh, C. Gan, The impact of the COVID-19 lockdown on stock market performance: evidence from Vietnam, in: Journal of Economic Studies, Emerald, 2020. DOI: https://doi.org/10.1108/JES06-2020-0312

[3] E. F. Fama, Efficient capital markets: a review of theory and empirical work, The Journal of Science 25(2) (1970) 383-417. DOI: https://doi.org/10.1111/j.15406261.1970.tb00518.x

[4] E. Tandelilin, Portfolio dan Investasi: Teori dan Aplikasi, Kanisius, 2020.

[5] G. Foster, Financial Statement Analysis, Second Edition, Prentice-Hall, 1986.

[6] I. Fahmi, Y. L. Hadi, Teori Portfolio dan Analisis Investasi: Teori dan Soal Jawab, Alfabeta,, 2009.

[7] I. Nurmasari, Dampak COVID-19 terhadap perubahan harga saham dan volume transaksi (studi pada PT. Ramayana Lestari Sentosa, Tbk., in: Jurnal Sekuritas (Saham, Ekonomi, Keuangan dan Investasi),ProdiManajemenUniversitas 
Pamulang, Tanggerang Selatan, Banten, 2020, pp. 230-236. DOI: $10.32493 /$ skt.v3i3.5022

[8] J. Hartono, Teori Portfolio dan Analisis Investasi, BPFE, 2016.

[9] M. H. Rifa'i, Junaidi, A. F, Sari, Pengaruh peristiwa pandemic covid-19 terhadap indeks harga saham gabungan, Junal Ilmiah Riset Akutansi, Fakulats Ekonomi \& Bisnis Usima, Malang, East Java, pp. 41-53.

[10] M. Simatupang, Pengetahuan Praktisi Investasi Saham, Mitra Wacana Media, 2010.

[11] M. Topcu, O. S. Gulal, The impact of COVID-19 on emerging stock market, in: Finance Research Letters, Elsevier, Amsterdam, 2020, pp. 1-4. DOI: https://doi.org/10.1016/j.frl.2020.101691

[12] R. B. Pasaribu, Value at risk portfolio dan Likuiditas Saham, Jurnal Akutansi \& Manajemen, Pusat Penelitian dan Pengabdian Masyarakat STIE YKPN Yogyakarta, Yogyakarta, Special Region Yogyakarta, 2010, pp. 105-127.

[13] S. Husnan, Dasar-Dasar Teori Portfolio dan Analisis Sekuritas, UPPAMP YPKN, 2005.

[14] Sugiyono, Metode Penelitian Kuantitatif, Kualitatif, dan R\&D, PT Alfabet, 2016.

[15] Z. Bodie, A. Kane, A. J. Marcus, Investments, McGraw-Hill Education, 2014. 